\title{
High hydrostatic pressure inactivation of total aerobic bacteria in raw meatball
}

\author{
Yüksek hidrostatik basınçla çiğ köftede toplam aerobik bakteri \\ inaktivasyonu
}

\author{
Sinan UZUNLU ${ }^{1 *}$, Keshavan NIRANJAN \\ ${ }^{1}$ School of Applied Sciences, Pamukkale University, Denizli, Turkey. \\ suzunlu@pau.edu.tr \\ 2Department of Food \& Nutritional Sciences, University of Reading, Whiteknights, Reading, Berkshire RG6 6AP, UK. \\ afsniran@reading.ac.uk
}

\section{Abstract}

The current study aimed at the improvement of raw meatball (Cig Kofte) safety, by using high hydrostatic pressure (HP) treatment. Beef mince, one of the main raw material of meatball, was treated by high HP at $400 \mathrm{MPa}$ for 15 minutes at $22^{\circ} \mathrm{C}$. After the HP treatment, 3decimal reduction was achieved, by measuring total viable counts. HP treated and non-treated (control) beef mince were used in Cig Kofte preparation for evaluation. Any colour change was observed visually between the HP treated and control group samples. Indigenous microbial load of beef mince was inactivated by high HP that increased safety of traditional Turkish food. Therefore, it is proposed to process meat with high HP to prepare a safe ready-to-eat Cig Kofte.

Keywords: High hydrostatic pressure, Raw meatball, Food safety, Traditional foods

\section{Introduction}

Raw meatball (Cig Kofte) is a traditional Turkish food, consumed as an appetizer in Turkey. It is mainly belonged with Şanlıurfa, a city of South-East Turkey. It constitutes beef or lamb meat, bulgur (boiled and pounded wheat), tomato or red pepper paste, spices and condiments such as paprika, black pepper, salt etc. Those materials are hand kneaded and served immediately for consuming. It carries out a food poisoning risk because of consuming in raw form and treating any inactivation process for the indigenous microbial load. Apart from those, leftovers might be refrigerated for overnight and unhygienic preparation, as well, is considered [1],[2].

Meat, representing one of the main raw material of Cig Kofte, determines the survivability of pathogenic and spoilage microorganisms. The composition of meat is composed of carbohydrates, protein, fat and trace mineral elements. In addition, presence of water in meat supports microbial growth, too. From a microbiological perspective, meat stands for an ultimate food for growth of organisms [3].

There are a number of researchers documented that Cig Kofte has high microbial load, for instance total aerobic mesophilic bacteria counts were in the range of 4 and 7 logs, Coliforms were between 2 to $5 \operatorname{logs}$, Staphylococcus aureus were in the range of 2 to 5 logs [4]-[9]. Even, Salmonella spp. was isolated by Cetin et al. [5], Cetinkaya et al. [7] and Pekel et al. [9] Additionally, parasites were also observed by Cetin et al. [5]. A trichenollosis outbreak was related with consumption of Cig
Öz

Bu araștırma, Ciğ Köftenin güvenliğini yüksek hidrostatik basinç (HP) kullanarak arttırmayı amaçlamıștır. Çiğ Köftenin iki ana hammaddesinden birisi olan dana kiyma etine $22^{\circ} \mathrm{C}$ 'de 15 dakika süre ile $400 \mathrm{MPa}$ 'da yüksek HP uygulanmıștır. HP sonrası toplam canlı sayımlarında 3 desimal azalma sağlanmıștır. Çiğ Köfte yapımında HP uygulanmıs ve uygulanmamıs (kontrol) dana eti kullanılarak değerlendirmeye alınmıștır. HP ve kontrol grupları arasında görsel olarak herhangi bir renk değişikliği görülmemiștir. Dana etinin başlangıç mikrobiyal yükü yüksek HP ile inaktif edilerek geleneksel bir gıda olan Ciğ Köftenin güvenliği arttırılmıștır. Bu nedenle güvenilir tüketime hazır bir Çiğ Köfte yapımı için, etin yüksek HP ile proses edilmesi önerilmektedir.

Anahtar kelimeler: Yüksek hidrostatik basınc, Ciğ köfte, Gıda güvenliği, Geleneksel gıdalar

Kofte that replaced with pork meat [10]. It can be easily imitated in markets with other meat types, too. Cetin et al. [5] demonstrated that 34 out of 102 retailed Cig Kofte samples were composed of equine, beef and mutton, beef and poultry, equine and poultry, in Istanbul.

There were attempts to overcome such those risks related with Cig Kofte, such as gamma irradiation treatment by Ylldırım et al. [1], Vural et al. [11], Gezgin et al. [12], and Gumus et al. [13]. Those studies reported the great potential for industry by decreasing the indigenous microbial load or artificially inoculated bacteria on Cig Kofte. However, consumer's negative perception is a major concern for such foods, as well regulations. Therefore, we were driven to bring a solution to inactivate indigenous viable counts, present in beef meat, by high hydrostatic pressure (HP) without changing the colour of final product.

High HP, namely as an alternative minimal food preservation technique, is being applied by using an instrument. Mainly, water is used for pressure transmission medium in a pressure vessel. Foods packed in their final flexible packaging material and high pressure is applied in a range of $100 \mathrm{MPa}$ to $1000 \mathrm{MPa}$ for several seconds to minutes. First use was in 1899 in milk, fruit juice, meat and a variety of fruits at $658 \mathrm{MPa}$ for 10 minutes in the USA. Unavailability of proper processing discontinued the HP in both research and industry. However, 1980s was the period of reusing HP by advanced equipment and packaging materials. Mainly, jams were the foods processed in Japan by HP. Today, in many countries meat and 
poultry products is also being processed with HP to achieve a considerable shelf life [14],[15].

Therefore, current research aimed at inactivation of total aerobic mesophilic bacteria in raw meat ball preparation, by using high HP treatment.

\section{Materials and methods}

Peptone Water 0.1\%, TSA (Tryptic Soy Agar) and 1.2Propanediol were purchased from Sigma-Aldrich (United Kingdom). Beef mince, onion, spring onion, tomato paste, black pepper and salt were purchased from local markets in Reading/Berkshire (United Kingdom). Beef mince samples were purchased from two different suppliers. Bulgur and gamma irradiated red pepper were purchased from Antalya (Turkey).

\subsection{High hydrostatic pressure treatment}

Fifty grams of beef mince samples were inserted into polyethylene bags, sealed by vacuum using a Multivac A 300 model instrument and applied high HP at $400 \mathrm{MPa}$ for 15 minutes at Pilot Plant of University of Reading Food and Nutritional Sciences Department (UK) using a Stansted Fluid Power Ltd (UK) high pressure instrument. Sample holder inlet temperature of the unit during the treatment was recorded as $22^{\circ} \mathrm{C}$. Pressurizing medium was 1.2-Propanediol.

\subsection{Cig Kofte preparation}

A total of 250 grams bulgur, 200 grams of beef mince, 80 grams onion, 60 grams irradiated paprika, 50 grams tomato paste, 40 grams spring onion, 5 grams salt and 1.45 grams black pepper were used to prepare Cig Kofte samples. Onion and spring onion were kneaded and dipped into citric acid-water solution $(\% 2.5 \mathrm{w} / \mathrm{v})$ for an hour to decrease microbial load. After processing with high pressure all raw materials were hand kneaded for about 30 min on a metallic bench. Samples were aseptically placed in polyethylene bags ( $40 \mathrm{~g}$ each) and vacuum packaged by using a Multivac A 300 packaging unit at pilot plant facilities. Bags were then immediately transferred to laboratory, kept there at $4{ }^{\circ} \mathrm{C}$ until being analysed. Two suppliers' beef constituted 2 samples groups, and duplicate bags were grouped for high pressured samples and control (untreated) samples.

\subsection{Enumeration of total aerobic mesophilic bacteria}

10 grams of samples were weighed in sterile stomacher bags containing $90 \mathrm{~mL}$ of peptone water $(0.1 \%)$ and homogenised in a stomacher (Seward 400, UK) at $230 \mathrm{rpm}$ for two minutes. Serial decimal dilutions were prepared and spread onto TSA. Plates were incubated at $37^{\circ} \mathrm{C}$ for $24-48$ hours prior to counting colonies.

\section{$2.4 \quad$ Statistical analysis}

Each trial was repeated twice and duplicate samples were tested at each sampling time. All survived bacterial plate count data were subjected to ANOVA (one-way analysis employing (SPSS, IBM) 21 (USA)) in order to determine the differences of high HP effect on microbial counts. Duncan's post hoc test was applied at a significance level of $\mathrm{p}<0.05$.

\section{Results and discussion}

Total aerobic mesophilic bacteria counts were found 3 logarithmic units (Table 1) in both of the suppliers of beef mince samples. Taking account of the Cig Kofte samples' total aerobic mesophilic bacteria counts were similarly with beef mince samples, it is therefore rest of the materials, used in preparation, were not additionally increased the final product's microbial load (Table 1). Receipt of the Cig Kofte were deliberately modified in order to control the microbial load of final product. Using gamma irradiated paprika, leaving chopped onion and spring onion in citric acid-water solution $(2.5 \% \mathrm{w} / \mathrm{v})$ were the attempts to reach this aim. Results showed that total viable counts of the Cig Kofte were mainly depended on beef samples (Table 1). It is well known that, meat contains indigenous microorganisms that needs to be inactivated before consuming.

Modifying intrinsic factors of meat, such as water activity $\left(a_{w}\right)$, results increased lag phase of microbial growth and decreased growth rate. In addition, changing $\mathrm{pH}$, relative humidity, temperature and gaseous atmosphere for extrinsic factors of meat provides decreased microbial growth. For instance, under refrigeration temperatures psychrophilic microorganisms grow slowly, as well express different genes and display physiological difference than mesophilic organisms [3].

Whether above listed factors affect microbial growth, there is another solution required that will be resulted rapid microbial decrease than those. Because Cig Kofte is consumed mostly in the same day of preparation, moreover immediately after the preparation in-house consuming, the required period for decreasing microbial growth is limited.

There are too many processes being applied in food technology to overcome microbial growth. High HP is one of those technologies to inactivate microbial growth and inhibit enzymes. Ready-to-eat meat products, such as pastrami and Cajun beef, were treated at $600 \mathrm{MPa}$ at $20^{\circ} \mathrm{C}$ for $3 \mathrm{~min}$ and stored at $4{ }^{\circ} \mathrm{C}$ for 98 days without having limited or no growth for spoilage and pathogenic organisms. Moreover, consumers perceived any difference between the control and processed meat samples [14].

Moreover, barosensitivity of microorganisms is varied. Yeasts and Gram ( - ) bacteria are more sensitive organisms than moulds and Gram (+) bacteria. For example 6.63 logarithmic unit of Listeria innocua, mostly used as a surrogate of Listeria monocytogenes, were inactivated at $450 \mathrm{MPa}$ at $20^{\circ} \mathrm{C}$ for $10 \mathrm{~min}$ in minced beef muscle. Common pathogens such as Escherichia coli and Salmonella spp. were also studied in foods by handling HP [14]. There are a number of papers documented the effective use of high pressure in literature for further reading [16]-[19].

Current study resulted a 3 -decimal reduction significantly $(P<0.05)$ in total aerobic mesophilic bacteria counts in beef mince samples (Table 1), by using high HP treatment. However, 5 logarithmic unit reduction is required for processors of HP, to ensure the safety of foods by the specification of National Advisory Committee on Microbiological Criteria for Foods (NACMCF), in 2006 [15].

In case of the appearance, the colour of the beef mince was changed after high pressure treatment (data not shown). However, it was impossible to distinguish visually the Cig Kofte samples whether it is prepared by using high pressured beef mince or not (data not shown).

It is documented that conversion of myoglobin to metmyoglobin at pressures greater than $400 \mathrm{MPa}$ resulted to colour losses in meat [20]. $200 \mathrm{MPa}$ and $400 \mathrm{MPa}$ results 
denaturation of actomyosin and myglobin, respectively. Moreover, lipids in meat become more susceptible to oxidation above $400 \mathrm{MPa}$ by high pressure processing [21].

However, if meat planned to be used in restaurants there is any concern with its colour [22],[23]. It is complied with our results for Cig Kofte preparation.

Table 1: Effect of high HP treatment on total aerobic mesophilic bacteria counts (Log CFU/g).

\begin{tabular}{ccc}
\hline Supplier 1 & Cig Kofte & Beef mince \\
\hline Control & $3.60 \pm 0.077 \mathrm{a}$ & $3.65 \pm 0.113 \mathrm{c}$ \\
Treated & $<0.01 \mathrm{~b}$ & $<0.01 \mathrm{~d}$ \\
Supplier 2 & Cig Kofte & Beef mince \\
Control & $3.51 \pm 0.374 \mathrm{a}$ & $3.29 \pm 0.091 \mathrm{e}$ \\
Treated & $<0.01 \mathrm{~b}$ & $<0.01 \mathrm{~d}$ \\
\hline
\end{tabular}

Data in the same column bearing different letters (a, b, c, d, e) are significantly different $(\mathrm{p}<0.05)$ and expressed as mean \pm standard deviation.

Attempts were performed by many researchers to decrease the health risk of Cig Kofte, handling various food processes. Apart from the gamma irradiation, one of those is excluding the beef from the ingredients, so as to decrease the microbial risk. Even in this novel form of Cig Kofte, it has been found that retailed samples contaminated with Listeria monocytogenes in 12 out of the 70 samples in Ankara, Turkey [24]. In addition, pomegranate sauce, plum sauce and lemon juice were used in Cig Kofte preparation [25]. When those materials were direct used against Salmonella Enteritidis, Salmonella Typhimurium, Escherichia coli, Staphylococcus aureus and Bacillus spp., high antibacterial effect were observed, in vitro. However their use as ingredient in Cig Kofte preparation, resulted low antimicrobial effect on Coliform, E.coli and total aerobic mesophilic microorganisms. Researchers stated that plum sauce and pomegranate sauce decreased the total viable counts one logarithmic cycle, in comparison with control samples. While, slight effect was observed against Coliform and E.coli [25].

A recent study, reported using yoghurt and yoghurt serum in order to decrease the microbial load of the Cig Kofte. The study indicated replacing water with yoghurt and yoghurt serum in the formulation. Researchers stated its potential for preventing foodborne pathogens in Cig Kofte [8].

In conclusion, Cig Kofte has any processing step, in its own receipt, which eliminates indigenous microbial load during hand-kneading preparation before consuming.

Therefore, it is considered to apply high HP on beef mince to inactivate microorganisms, without perceiving any colour losses in the final product. The results of the current study indicate that high HP treatment is a promising attempt from an industrial standpoint. Whether this study reports the preliminary results, it might be designed extensively in order to document an accurate output in future.

\section{Acknowledgements}

Society of Chemical Industry (SCI), London/UK is acknowledged for awarding an AJ Banks travel bursary to Sinan Uzunlu, in 2015. The assistance provided by Sameer Khalil Ghawi at the University of Reading is also appreciated.

\section{References}

[1] Yıldırım I, Uzunlu S, Topuz A. "Effect of gamma irradiation on some principal microbiological and chemical quality parameters of raw Turkish meat ball". Food Control, 16(4), 363-367, 2005.
[2] Kilic B. "Current trends in traditional Turkish meat products and cuisine". LWT-Food Science and Technology, 42(10), 1581-1589, 2009.

[3] Cutter, CN, Senevirathne RN, Chang VP, Cutaia RB, Fabrizio KA, Geiger AM, Valadez AM, Yoder SF. Major microbiological hazards associated with packaged fresh and processed meat and poultry. Editor: Kerry JP. Advances in Meat, Poultry and Seafood Packaging, 3-58, Cambridge, UK, 2012.

[4] Uzunlu S, Yıldırım I, Serdengecti N. "Microbiological quality of raw meat ball consumed in Antalya". Journal of the Turkish Microbiological Society, 34(4), 257-261, 2004.

[5] Cetin O, Bingol EB, Akkaya H. "The microbiological, serological and parasitological quality of Cig Kofte (Raw Meatball) and its lettuce marketed in Istanbul". Polish Journal of Environmental Studies, 17(5), 701-706, 2008.

[6] Ardic M, Durmaz H. "Determination of changes occurred in the microflora of cig kofte (raw meat balls) at different storage temperatures". International Journal of Food Science and Technology, 43(5), 805-809, 2008.

[7] Cetinkaya F, Mus TE, Cibik R, Levent B, Gulesen R. "Assesment of microbiological quality of cig kofte (raw consumed spiced meatball): Prevalence and antimicrobial susceptibility of Salmonella". Food Control, 26(1), 15-18, 2012.

[8] Dogan M, Cankurt H, Toker OS, Yetim H, Sagdic O. "Effect of yoghurt or yoghurt serum on microbial quality of cig kofte". Journal of Food Science and Technology, 51(7), 1406-1410, 2014.

[9] Pekel Ç, Var I, Kabak B, Şener A, Burcu Ö. “Çiğ köftelerin mikrobiyolojik kalitesi”. I. Bölgesel Öğrenci Gıda Sempozyumu Adana'03, Adana, Türkiye, 17-18 Nisan 2003.

[10] Dagdeviren M. "İzmir'de Domuz Etli Cig Kofte Panigi”. http://www.habervitrini.com/gundem/izmirde-domuzetli-cig-kofte-panigi-115228/ (05.01.2016).

[11] Vural A, Aksu H, Erkan ME. "Low-dose irradiation as a measure to improve microbiological quality of Turkish raw meat ball (cig kofte)". International Journal of Food Science and Technology, 41(9), 1105-1107, 2006.

[12] Gezgin Z, Gunes G. "Influence of gamma irradiation on growth and survival of Escherichia coli 0157: H7 and quality of cig kofte, a traditional raw meat product". International Journal of Food Science and Technology, 42, 1067-1072, 2007.

[13] Gumus T, Demirci AŞ, Velioglu HM, Velioglu SD, Yilmaz I, Sagdic 0. "Application of gamma irradiation for inactivation of three pathogenic bacteria inoculated into meatballs". Radiation Physics and Chemistry, 77(9), 10931096, 2008.

[14] Fellows PJ. Food Processing Technology. $3^{\text {rd }}$ ed. Cambridge, UK, Woodhead Publishing Limited, 2009.

[15] Daryaei H, Balasubramaniam VM. Microbial decontamination of food by high pressure processing. Editors: Demirci A, Ngadi MO. Microbial Decontamination in the Food Industry, 370-406, Cambridge, UK, Woodhead Publishing Limited, 2012.

[16] Heinz V, Knorr D. Effects of high pressure on spores. Editors: Hendrickx MEG, Knorr D. Ultra High Pressure Treatments of Foods, 77-113, New York, USA, Springer Science + Business Media, 2001. 
[17] Tewari G. "Method to extend the shelf-life of food products using hydrostatic high-pressure processing". US Patent Application Publication, USA, US 2005/0112252 A1, 2005.

[18] Knorr D, Heinz V, Buckow R. "High pressure application for food biopolymers". Biochimica et Biophysica Acta, 1764(3), 619-631, 2006.

[19] Legan JD, Chapman BL, Bull MK. "Process for reducing spore levels in compositions". US Patent Application Publication, USA, US 2010/0104721 A1, 2010.

[20] Gill A, Gill CO. Microbial decontamination of raw and readyto-eat meats. Editors: Demirci A, Ngadi MO. Microbial Decontamination in the Food Industry, 30-59, Cambridge, UK, Woodhead Publishing Limited, 2012.

[21] Ma H, Ledward DA. "High pressure processing of fresh meat-Is it worth it?". Meat Science, 95(4), 897-903, 2013.
[22] Carlez A, Veciana-Nogues T, Cheftel JC. “Changes in colour and myoglobin minced beef meat due to high pressure processing". LWT-Food Science and Technology, 28(5), 528-538, 1995

[23] Jung S, Ghoul M, De Lamballerie-Anton M. "Influence of high pressure on the color and microbial quality of beef meat". LWT-Food Science and Technology, 36(6), 625-631, 2003.

[24] Taban MB. "Listeria monocytogenes in cig kofte without meat: A novel bulgur ball product". Journal of Food, Agriculture \& Environment, 10(2), 130-132, 2012.

[25] Var I, Kabak B. “Çiğ Köfte Yapımında Erik Ekstraktı, Nar Ekșisi ve Limon Suyu Kullanımının Antimikrobiyal Etkilerinin Araştırılması". Çukurova Üniversitesi, Adana, Türkiye, Bilimsel Araştırma Projeleri Sonuç Raporu, ZF/2003/YL49, 2005. 